\title{
NASA carpeted over Space Shuttle costs
}

THE US National Aeronautics and Space Administration, deeply embroiled in technical problems over the final stages of the Space Shuttle development programme, is facing what some employees are already referring to as the worst setback to have hit the agency since the launch-pad fire in the Apollo programme. Last Friday, President Carter asked the US Congress for a budget amendment that would increase NASA's budget for 1980 by $\$ 220$ million over the present request of $\$ 4.6$ billion to absorb the extra costs of the Shuttle programme (the need to accommodate which had already led to the exclusion of any new starts in the 1980 budget).

The request for the extra money followed the revelation two weeks ago by Dr Robert Frosch, administrator of NASA, that the agency was now expecting cost over-runs due to last minute delays in the Shuttle programme to exceed $\$ 600$ million over the next four years. This figure is considerably higher than estimates provided earlier this year to Congressional committees in their discussion of NASA's 1980 request, during which agency officials gave little indication that the projected budget would be insufficient.

In a sharply worded letter sent to $\mathrm{Dr}$

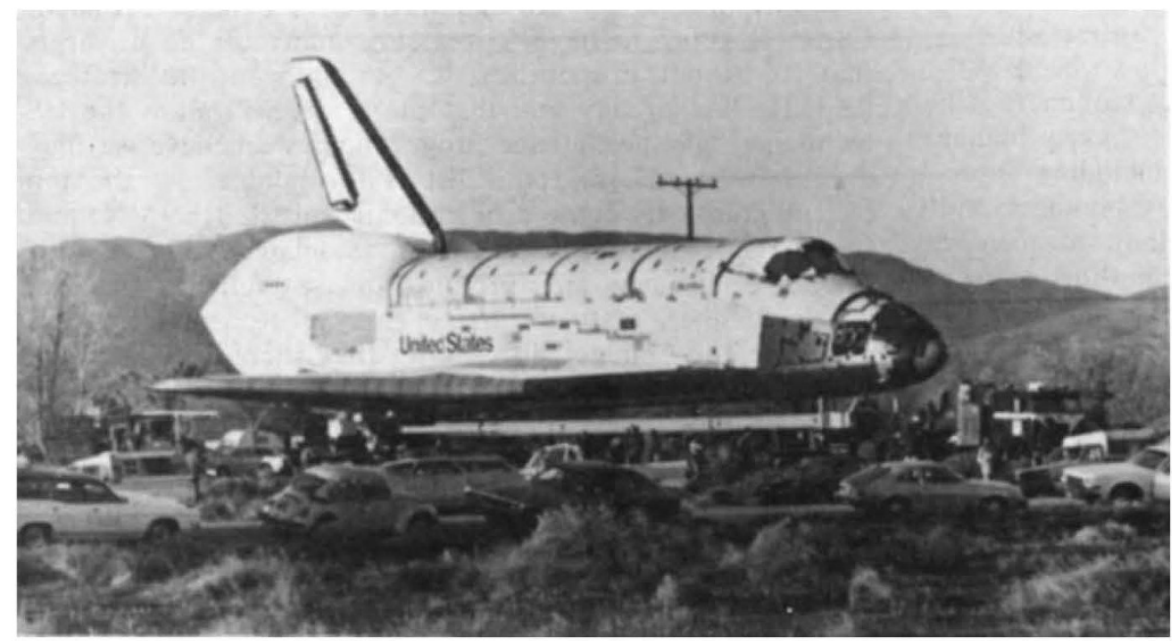

Fixing the heat resisting tiles is proving difficult

Frosch last week, Senators Howard Cannon, Adlai Stevenson $\mathrm{Jr}$ and Jack Schmitt, of the Senate Committee on Commerce, Science and Transportation, say that the failure to alert the committee about the critical funding situation was "most regrettable". "The current situation seriously threatens that committee's credibility as well as NASA's. This condition must be rectified promptly", wrote the three members of the Committee, which is responsible for recommending the agency's budget to the Senate.

The three committee members say that a thorough review and identification of specific failures, together with a statement of corrective action initiated or proposed, is necessary. "Coupled with support for the optimum solution, which will be reflected in the bill the committee recommends to the Senate, is the need for a forthright explanation of why we are confronted with the present situation and concrete assurance that management deficiencies are corrected."

Dr Frosch told the committee members at the end of last week that NASA has already established an inquiry, under the direction of Dr Alan M. Lovelace, deputy administrator of the agency, to look into the causes of the current production delays and cost

\section{US signs treaties on scientific links with China and Japan}

Mrs Juanita Kreps, US secretary of commerce, and deputy Chinese prime minister Fang Yi, last week signed four agreements on scientific and technological cooperation in fields ranging from weather monitoring to tuna fishing.

The agreements allow for Chinese scientists to work on measurements and standards at the Bureau of Standards in Maryland, and at the over-runs. Within the agency there are already rumours that several heads might fall as a result of the inquiry.

The main technical problem facing the Shuttle, whose first flight is officially still scheduled for November but now seems unlikely to take place before the end of the year, is at present the task of fixing the heat-resistant tiles to the surface of the re-entry vehicle. Although the tiles were meant to be fixed at a current rate of about 500 a week, problems in handling and fixing the tiles to the surface of the vehicle have meant that progress is nowhere near that figure.

At present NASA hopes that with the increased funding that it is requesting (in addition to the budget amendment, the agency has also put in for an extra $\$ 185$ on top of its 1979 budget), as well as a rescheduling of some of the early flight plans, the delays will have a minimal impact on any of the planned space science operations. But in a time of general financial stringency, there have already been moves in the House of Representatives to reduce Space Shuttle funding to provide more money for mass transportation. And although these have so far been unsuccessful, if Congress refuses to grant the extra money, a number of projects could be in peril.

Already representative Edward $P$. Boland, chairman of the House Appropriations subcommittee responsible for NASA's budget, has said that he believes money could be taken out of both the Space Telescope and the Galileo Jupiter mission to help cover some of the additional Shuttle costs. Officials with the European Space Agency are concerned that any delay in the Spacelab launch, currently scheduled for August 1981, could add considerable additional costs to a project which has already over-run estimates by $40 \%$.

Precise details of NASA's plans are likely to emerge in new hearings which the Senate Science and Space Subcommittee, chaired by Senator Stevenson, is planning to hold on the budget amendment request. David Dickson
Severe Storm Center in Oklahoma. US scientists will visit Peking, where the agreements were signed, to computerise the Chinese weather-forecasting system, and to train Chinese in the use of the US technology which they are planning to import.

Exactly one week earlier, the US and Japanese governments signed an agreement in Washington on cooperation in research and development in energy and related fields, the outcome of a Japanese initiative to President Carter last May.

Areas covered by the latter agreement include fusion research-with the Japanese planning to participate in the Doublet III magnetic fusion project-coal conversion, solar energy conversion through photosynthesis, geothermal energy, and high energy physics. 